Szkoła Główna Handlowa w Warszawie e-mail: ewa.jastrzebska@sgh.waw.pl ORCID: 0000-0002-0029-6943

Szkoła Główna Handlowa w Warszawie e-mail: halina.brdulak@sgh.waw.pl ORCID: 0000-0001-9125-0010

Tomasz J. Dąbrowski Szkoła Główna Handlowa w Warszawie e-mail: tdabro1@sgh.waw.pl ORCID: 0000-0002-0594-6642

Paulina Legutko-Kobus Szkoła Główna Handlowa w Warszawie e-mail: plegut@sgh.waw.pl ORCID: 0000-0003-0380-8913

\title{
SPOŁECZNA ODPOWIEDZIALNOŚĆ UCZELNI. PERSPEKTYWA STRATEGICZNA
}

\section{Abstract \\ University social responsibility: Strategic perspective}

The article characterizes the essence of university social responsibility (USR). Various approaches to SRU strategy implementation are presented. The methods and scope of the USR strategy were discussed. The role of stakeholders and the entity responsible for the strategy were indicated.

Keywords: university social responsibility, university social responsibility strategy, sustainability, stakeholders

\section{Streszczenie}

W artykule scharakteryzowano istotę społecznej odpowiedzialności uczelni(SOU). Przedstawiono różne podejścia do wdrażania strategii SOU. Omówiono metody i zakres strategii SOU, wskazano sposoby włączania interesariuszy i rolę podmiotu odpowiedzialnego za wdrażanie strategii. 
Słowa kluczowe: społeczna odpowiedzialność uczelni, strategia społecznej odpowiedzialności uczelni, zrównoważony rozwój, interesariusze

\section{Wstęp}

Koncepcja społecznej odpowiedzialności biznesu (ang. corporate social responsibility, CSR) rozwija się jako odpowiedź biznesu na wyzwania współczesnego świata. $\mathrm{Z}$ jednej strony boryka się on $\mathrm{z}$ coraz dotkliwszymi problemami globalnymi, z drugiej - coraz częściej głos zabiera zaangażowane społecznie pokolenie tzw. millenialsów. Postulaty godziwej pracy dla wszystkich oraz rozsądnego użytkowania ograniczonych zasobów naturalnych stają się zatem coraz powszechniejsze. W takiej rzeczywistości biznes nie może się ograniczać tylko do generowania zysków, lecz powinien także myśleć o wpływie, jaki wywiera na swoje bliższe i dalsze otoczenie. Budowanie świadomości dotyczącej tych zmian i ich skutków spoczywa również na podmiotach, które w swojej misji mają działalność edukacyjną - w tym szkołach wyższych.

Wielu badaczy stoi na stanowisku, że społeczna odpowiedzialność jest nieodłącznym elementem misji uczelni. Uczelnie kształcą, wyposażając studentów i słuchaczy w odpowiednią wiedzę, umiejętności i kompetencje (funkcja edukacyjna). Aby dostarczać wiedzy jak najbardziej aktualnej, uczelnie prowadzą badania naukowe, których wyniki są popularyzowane i komercjalizowane (funkcja badawcza). Tych dwóch funkcji nie da się spełniać w izolacji, stąd zadaniem uczelni jest także współpraca i kształtowanie relacji z szeroko pojętym otoczeniem na rzecz rozwoju całego społeczeństwa - służba społeczeństwu (funkcja społeczna) [Leja, 2009]. Jednak coraz powszechniejszy staje się pogląd, że bycie podmiotem nastawionym na kształcenie istotne dla społeczeństwa i kształtowanie postaw mających na względzie dobro publiczne nie czyni uczelni automatycznie społecznie odpowiedzialną. Społecznie odpowiedzialna uczelnia nie tylko kształci odpowiedzialnych społecznie absolwentów, lecz także sama postępuje w ten sposób, promując takie postawy wśród swoich pracowników i studentów. Rosną i zmieniają się w tym zakresie oczekiwania różnych interesariuszy wobec uczelni, czego przykładem mogą być chociażby wymagania instytucji akredytacyjnych, na przykład AACSB International, wobec uczelni biznesowych co do programów etycznych czy polityk różnorodności. $Z$ tego też powodu coraz więcej uczelni decyduje się na budowanie i komunikowanie strategii w zakresie społecznej odpowiedzialności.

Wychodząc z tych założeń, artykuł koncentruje się na określeniu istoty społecznej odpowiedzialności uczelni (SOU). Realizacja tego celu oparta jest na krytycznej analizie literatury przedmiotu. Celem artykułu jest także charakteryzowanie strategii SOU, która może stanowić podstawę wdrażania tej koncepcji. Ta część powstała z wykorzystaniem desk research (analizy źródeł internetowych oraz dokumentów wybranych uczelni) i prezentuje dobre praktyki (zidentyfikowane na podstawie web research z wykorzystaniem wyszukiwarki Google) ilustrujące różnorodność podejść do strategii SOU. 


\section{Społeczna odpowiedzialność uczelni — istota koncepcji}

Zdaniem Azama Esfijani’ego [2014: 30-41] idea społecznej odpowiedzialności szkół wyższych dyskutowana była w literaturze od lat 80 . XX wieku z użyciem różnej terminologii - najpierw w amerykańskim ujęciu scholarship of engagement (autorem tego terminu był Ernest L. Boyer [1996]) lub engaged scholarship, potem w kategoriach university community i civic/public engagement (Australia i Wielka Brytania), wreszcie - social responsibility of university i university social responsibility (USR, nawiązujące do CSR, a niekiedy z nim utożsamiane), podejściu przyjętym w Europie i Azji. Interpretacja najbardziej zbliżona do współczesnego, szerokiego rozumienia społecznej odpowiedzialności organizacji prezentowana jest $\mathrm{w}$ nurcie USR i dlatego też w niniejszym artykule ograniczono się do analizy definicji USR/SOU, wybierając te najczęściej stosowane i przedstawiające różne aspekty analizowanej koncepcji.

Juan Reiser [2007] zdefiniował USR jako etyczną jakość działania społeczności akademickiej (studentów, wykładowców i pracowników administracyjnych) zapewnioną przez odpowiedzialne zarządzanie edukacyjnym, poznawczym, kadrowym oraz środowiskowym wpływem uczelni, prowadzone w interaktywnym dialogu ze społeczeństwem w celu promowania zrównoważonego rozwoju ludzkości. Na znaczenie dialogu z interesariuszami zwrócił uwagę również Krzysztof Leja [2008: 61-62], który podkreślił, że uczelnia społecznie odpowiedzialna, aby stała się organizacją służącą otoczeniu, musi pozytywnie, lecz nie bezkrytycznie odpowiadać na oczekiwania interesariuszy, a stopień realizacji tych oczekiwań jest miarą jej społecznej odpowiedzialności. Podkreślając znaczenie interesariuszy, Mehran Nejati, Azadeh Shafaei, Yashar Salamzadeh i Mohammadreza Daraei [2011: 442] zwrócili uwagę, że interesariusze dają uczelniom przyzwolenie na działanie (ang. license to operate) i żeby wzmocnić tę umowę społeczną, uczelnie powinny być społecznie odpowiedzialne.

Podobnie jak Reiser, obszary USR określił także Erwin Eduardo Navarrete wraz z zespołem [2012: 10628], ujmując USR jako zdolność do rozpowszechniania i wdrażania licznych zasad i wartości za pomocą kluczowych procesów takich jak: zarządzanie, edukowanie, badania, rozszerzonych na społeczność, w celu zapewnienia zrównoważonego rozwoju. Wymiar etyczny SOU podkreśliła także Ewa Chmielecka [2008: 23], stwierdzając, że odpowiedzialna społecznie uczelnia to taka, która kultywuje pożądane wartości etosu akademickiego i działa zgodnie z jego wskazaniami. Podtrzymywanie etosu jest zaś warunkiem prawidłowego wypełniania przez uczelnię jej różnorodnych ról społecznych.

$\mathrm{Z}$ kolei na element aktywności na rzecz społeczeństwa zwróciły uwagę Ruxandra Vasilescu, Cristina Barna, Manuela Epure oraz Claudia Baicu [2010: 4178], stwierdzając, że w USR chodzi o etyczną potrzebę wzmacniania społecznego zaangażowania i aktywności obywatelskiej studentów i pracowników uczelni przez zachęcanie ich, by w ramach wolontariatu świadczyli usługi na rzecz lokalnej społeczności oraz promowali zrównoważony rozwój w skali lokalnej i globalnej. Szerzej ten „społeczny” wymiar odpowiedzialności uczelni ujęto w Guidelines 
for Universities Engaging in Social Responsibility [2017: 1], definiujących USR jako strategiczne zobowiązanie do traktowania społeczeństwa jako interesariusza uczelni oraz do działania zgodnie z tym zobowiązaniem, przy uwzględnieniu, że USR odnosi się do wszystkich aspektów wpływu uczelni na społeczeństwo, w odniesieniu do zarówno bezpośredniego zaangażowania na rzecz różnych grup interesariuszy, jak i wewnętrznych działań strategicznych.

Warto zwrócić uwagę na definicję wypracowaną w ramach projektu EU USR [University Social Responsibility..., 2015: 7-8], w której USR ujmuje się jako polityki, strategie i praktyki podejmowane przez uczelnie w celu zwiększania dobrobytu społecznego, kulturowego, gospodarczego i środowiskowego, podkreślając, że:

- USR to narzędzie promowania wartości obywatelskich i zrównoważonego rozwoju,

- niektóre aspekty USR powinny być obligatoryjne ze względu na to, że edukacja jest dobrem publicznym,

- USR stanowi zobowiązanie do transparentności i rozliczalności (ang. accountability).

Wyszedłszy zaś od ogólnej definicji społecznej odpowiedzialności według normy ISO26000, można uznać, że SOU to odpowiedzialność uczelni za wpływ jej decyzji i działań na społeczeństwo i środowisko przez przejrzyste i etyczne zachowanie, które: przyczynia się do zrównoważonego rozwoju, włączając w to zdrowie i dobrobyt społeczeństwa; uwzględnia oczekiwania interesariuszy; jest zgodne z mającym zastosowanie prawem i spójne z międzynarodowymi normami zachowania; jest wprowadzone w całej uczelni i praktykowane w jej działaniach w obrębie jej sfery wpływów [PKN, 2012: 16]. Warto zwrócić uwagę na tę definicję nie tylko dlatego, że rozszerza ona pojęcie społecznej odpowiedzialności biznesu na wszystkie organizacje i stanowi międzynarodowy konsensus wypracowany podczas wieloletniej dyskusji, lecz także ponieważ wyjaśnia zależność między społeczną odpowiedzialnością a zrównoważonym rozwojem, podkreślając, że społeczna odpowiedzialność skupia się na organizacji (uczelni), a nadrzędnym celem tej koncepcji jest maksymalizowanie wkładu organizacji (uczelni) w zrównoważony rozwój. Koncepcje CSR i zrównoważonego rozwoju początkowo rozwijały się równolegle, były różnie interpretowane, przez lata zmieniało się także zainteresowanie nimi. Po pewnym czasie zaczęto te nurty integrować, a w konsekwencji - stosować oba pojęcia zamiennie. Z tego powodu, mówiąc o SOU (powstałej w dużej mierze na gruncie CSR), nie sposób pominąć kwestii zrównoważonego rozwoju, na co wskazywała większość przytoczonych definicji. Warto również dodać, że w niektórych środowiskach biznesowych, a także w ONZ promuje się określenie „zrównoważony rozwój” jako najszerzej ujmujące zagadnienia związane $\mathrm{z}$ ekonomią, etyką i ekologią.

Już na podstawie tych kilku przedstawionych definicji wyraźnie widać, że podobnie jak w przypadku CSR, nie ma jednomyślności w definiowaniu SOU. Badacze prezentują odmienne podejścia, różniące się zakresem i kluczowymi pojęciami. Uniwersalna definicja ISO26000 [PKN, 2012] nie uwzględnia z kolei specyfiki uczelni. Azam Esfijani, Farookh Khadeer Hussain i Elizabeth Chang [2013: 274-276] przeanalizowali około czterdziestu definicji odnoszących się do 
idei społecznej odpowiedzialności szkół wyższych, zauważając, że większość badaczy, definiując tę koncepcję, używa pojęć takich jak: interesariusze (kategoria obejmująca: społeczność, społeczeństwo, studentów, rządy, biznes, środowisko i przemysł), zaangażowanie, odpowiedzialność, edukacja, badania, usługi, wiedza, nauczanie i etyka. Badacze zwrócili ponadto uwagę, że w dyskusji nad społeczną odpowiedzialnością szkół wyższych pomijany jest często aspekt transparentności, tak istotny dla CSR.

W Polsce tematyką SOU jako pierwsi zajęli się Krzysztof Leja [2008] i Marcin Geryk, który w latach 2007-2010 prowadził pionierskie badania $\mathrm{z}$ tego zakresu [Geryk, 2010; 2012]. Tematykę tę rodzimi badacze rozważali z różnych punktów widzenia, między innymi: etosu akademickiego [Chmielecka, 2008; Gałat, 2018], wizerunku [Białoń, Werner, 2012] i marki [Iwankiewicz-Rak, Shulgina, 2013], misji uczelni [Koj, 2013] oraz środowiska lokalnego [Szewior, 2018]. Wobec braku konsensusu w definiowaniu SOU wdrażanie tej koncepcji ułatwiają podjęte inicjatywy w tym zakresie, przede wszystkim kierowane do uczelni, bo skupiające się na tych elementach społecznej odpowiedzialności, które są charakterystyczne dla uczelni jako instytucji edukacyjnej. Pierwszą inicjatywą, o jakiej warto wspomnieć, jest deklaracja Talloires, opracowana w 1990 roku przez Association of University Leaders for a Sustainable Future. Do tej pory sygnowało ją ponad pięćset uczelni z ponad pięćdziesięciu państw [Talloires Declaration, 2019]. Deklaracja stanowi zobowiązanie do zrównoważonego rozwoju (w wąskim ujęciu: ekorozwoju) i ma postać planu działań składającego się z dziesięciu punktów. Zaliczono do nich nie tylko podnoszenie świadomości i edukowanie w zakresie zrównoważonego rozwoju czy podejmowanie działań ekologicznych, lecz także instytucjonalizację zrównoważonego rozwoju, angażowanie wszystkich interesariuszy i podejmowanie współpracy na rzecz interdyscyplinarnego podejścia do zrównoważonego rozwoju [The Talloires Declaration..., 1990]. Podobnych aspektów SOU dotyczy sześć zasad odpowiedzialnej edukacji menedżerskiej (The Principles for Responsible Management Education, PRME), ogłoszonych przez Global Compact ONZ w 2007 roku, kierowanych do uczelni kształcących na kierunkach biznesowych. PRME odnoszą się bowiem zarówno do kształcenia w zakresie zrównoważonego rozwoju i społecznej odpowiedzialności, jak i do prowadzenia w tym zakresie badań przy współpracy i w dialogu z otoczeniem [Six Principles, 2019]. Obecnie sygnatariuszami PRME jest siedemset pięćdziesiąt osiem uczelni z dziewięćdziesięciu państw (w tym siedem z Polski) [Search Participants]. Jedna trzecia ze stu najlepszych uczelni biznesowych według rankingu „Financial Times” to sygnatariusze PRME [PRME - The Principles..., 2019].

Szerzej niż wymienione wcześniej inicjatywy ujmuje SOU ogłoszona 20 listopada 2017 roku polska Deklaracja Społecznej Odpowiedzialności Uczelni, wypracowana przez grupę roboczą ds. edukacji i popularyzacji CSR funkcjonującą w ramach Zespołu ds. Zrównoważonego Rozwoju i Społecznej Odpowiedzialności Przedsiębiorstw, organu pomocniczego Ministra Rozwoju i Finansów. Deklaracja składa się z dwunastu punktów dotyczących oprócz wspomnianych już obszarów: edukacji, badań i projektów z zakresu społecznej odpowiedzialności i zrównoważonego rozwoju, współpracy w zakresie SOU i dialogu z interesariuszami, także 
odpowiedzialnego i przejrzystego zarządzania uczelnią, pielęgnowania wartości oraz minimalizowania negatywnego wpływu na środowisko [Deklaracja..., 2017]. Deklarację podpisały dwadzieścia trzy polskie uczelnie.

Podsumowując, standardy doprecyzowują różnie intepretowane pojęcie SOU, ułatwiając operacjonalizację tej koncepcji w praktyce. Budowanie SOU powinno zaś wiązać się z instytucjonalizacją tej idei.

\section{Różnorodność strategii społecznej odpowiedzialności uczelni}

Pojęcie strategii, podobnie jak społecznej odpowiedzialności, dalekie jest od jednoznaczności. Mimo dość powszechnie podzielanego poglądu na temat dużego znaczenia strategii dla organizacji istnieje niewiele zgody w środowisku akademickim w odniesieniu do tego, czym strategia rzeczywiście jest [Markides, 2004: 5]. W literaturze z zakresu zarządzania strategicznego wyodrębnia się wiele nurtów czy szkół reprezentujących różne sposoby patrzenia na strategię [Mintzberg i in., 1998; Obłój, 2007]. Niektóre z nich stanowią dobrą podstawę do dalszych rozważań nad strategią społecznej odpowiedzialności.

Najwcześniejszym i nadal najbardziej rozpowszechnionym sposobem ujmowania strategii jest rozpatrywanie jej w kategoriach opracowywanego przez naczelne kierownictwo organizacji długookresowego planu, w ramach którego definiowane są cele, zamierzenia i kierunki działania oraz alokowane są zasoby służące realizacji tych celów [Chandler, 1962]. Podejściu planistycznemu często przeciwstawiane jest podejście ewolucyjne [Lloyd, 1992]. Kwestionuje się w nim, jako nieodpowiadające rzeczywistości, założenie uporządkowanego przebiegu procesu konstruowania strategii. Zwraca się uwagę, że jej ostateczny kształt odbiega od przyjętych założeń czy planów, stanowi bowiem rezultat ścierania się odgórnych zaleceń i oddolnych inicjatyw, podejmowanych działań i wynikających z inercji zaniechań oraz prób bieżącego reagowania przez organizację na niekiedy dość gwałtowne i nieprzewidywalne zmiany zachodzące $w$ turbulentnym otoczeniu.

Jeszcze inne spojrzenie na strategię można odnaleźć w kolejnym nurcie akcentującym społeczny charakter procesu jej tworzenia. Przyjęcie takiej perspektywy oznacza, że istotną rolę w powstawaniu strategii odgrywa system wartości i przekonań podzielanych przez członków organizacji, który wpływa na to, jak rozumieją oni rzeczywistość i jak ją intepretują w związku z dokonywanymi wyborami. Wartości i przekonania stanowią najgłębszy poziom kultury organizacyjnej, będącej czynnikiem silnie oddziałującym zarówno na treść decyzji, jak i na sposób ich podejmowania, a później realizacji, a nawet na ocenę ich skutków. Proces tworzenia strategii może być rozpatrywany także w innych kategoriach władzy. W tym przypadku strategia jako wynik przetargu - odbywającego się między osobami, grupami a koalicjami mającymi rozbieżne, a niekiedy wręcz sprzeczne interesy - odzwierciedla układ sił w organizacji i służy realizacji interesów grup mających największy zakres władzy formalnej bądź nieformalnej. 
Czerpiąc z dorobku różnych nurtów reprezentujących odmienne podejścia, można zdefiniować strategię społecznej odpowiedzialności organizacji jako wynik procesu uzgodnień dotyczących wartości i zasad, jakimi będzie się kierowała organizacja, odnosząc się do zagadnień zgłaszanych przez jej interesariuszy, celów, jakie mają być realizowane w sferze społecznej odpowiedzialności, obszarów, w których polityka w tym zakresie będzie realizowana, oraz alokacji zasobów odpowiadającej celom i obszarom. Tak szerokie zakreślenie ram konceptualnych stanowi dobry punkt wyjścia do dalszych, bardziej szczegółowych rozważań dotyczących różnych aspektów strategii SOU.

Strategia SOU jest narzędziem zarządzania działaniami uczelni istotnymi z punktu widzenia jej interesariuszy (czyli osób lub grup, które są zainteresowane decyzjami lub działaniami organizacji). Pozwala koordynować działania podejmowane w tym zakresie (zwiększając ich efekt synergiczny) oraz lepiej je zintegrować ze strategią rozwoju i codziennym funkcjonowaniem uczelni. Dzięki strategii działania składające się na SOU nie są rozproszone, przypadkowe i nie wykluczają się nawzajem, a ich skuteczność wzrasta. Strategia SOU tworzy zatem trwałe i systemowe podstawy odpowiedzialnego działania oraz aktywnego dialogu z interesariuszami.

Istotą SOU jest dobrowolność (choć po podjęciu działań przekształca się ona w zobowiązanie), wieloaspektowość i elastyczność, wynikające częściowo także $\mathrm{z}$ braku jednolitego podejścia do tej koncepcji. Zaowocowało to różnorodnością strategii SOU zarówno w kontekście procesu ich budowania, jak i pod względem kształtu samego dokumentu. Każda uczelnia sama podejmuje decyzję, jak chce wdrażać SOU. Uwzględniając elementy składające się na SOU, wybór może dotyczyć: rodzaju strategii SOU, metody jej opracowania, sposobu zaangażowania interesariuszy w proces jej opracowania, zakresu strategii SOU oraz podmiotu odpowiedzialnego za jej realizację. Każdy z tych elementów zostanie pokrótce omówiony w dalszej części artykułu, w miarę możliwości z odniesieniem do praktyki.

Rodzaj strategii SOU. Dokument określający działania uczelni w zakresie społecznej odpowiedzialności może mieć charakter operacyjny (program lub polityka) bądź strategiczny (strategia albo będąca odrębnym dokumentem, albo wpisana w ogólną strategię rozwoju uczelni). Przenoszenie SOU na poziom strategiczny oraz stopień integracji SOU ze strategią rozwoju są wyrazem „dojrzałości” uczelni, bo wymagają świadomości zarządzających i zaangażowania pracowników. SOU w ujęciu strategicznym wpisane jest w DNA uczelni - począwszy od wizji, misji, motta i kluczowych wartości, przez cele strategiczne, polityki i programy, a kończąc na procedurach (na przykład rekrutacji czy awansu). Wpisując SOU w podstawową strategię rozwoju, można zapewnić, że wszystkie działania na rzecz realizacji tej koncepcji będą spójne i długofalowo przyczynią się do wdrażania zrównoważonego rozwoju.

University od Manchester jako pierwsza i jedyna brytyjska uczelnia wpisał SOU do swojej strategii rozwoju. W Manchester 2020. The University of Manchester's Strategic Plan (z 2011 roku, aktualizacja w 2015 roku) SOU jest jednym z trzech kluczowych celów strategicznych - obok światowej klasy badań (cel pierwszy) oraz wybitnej nauki i doświadczenia studenckiego (cel drugi). W ramach celu 
strategicznego dotyczącego SOU wyróżniono pięć priorytetów strategicznych: badania wywierające wpływ na społeczeństwo, społecznie odpowiedzialni absolwenci, angażowanie społeczności, odpowiedzialne procesy i ekorozwój [Manchester 2020..., 2015: 1, 19].

Zrównoważenie (ang. sustainability) to jeden z obszarów (obok równości i różnorodności, wzmocnienia jakości, społecznej odpowiedzialności i etyki), w ramach których University of the West of Scotland przedstawił oświadczenia i wytyczne służące osiągnięciu celów uczelni [UWS Commitments, 2019]. University of London zaprezentował założenia swojej SOU w oświadczeniu CSR, podzielonym na wiele szczegółowych zasad CSR, przypisanych do kluczowych działań podejmowanych przez uczelnię w nadrzędnych obszarach, takich jak: Londyn i świat, dostęp i doświadczenie studenckie, korzyści publiczne, współpraca, ekorozwój i zarządzanie organizacją [University of London, 2017: 1]. Te nadrzędne obszary wymienione zostały także w strategii rozwoju uczelni (przy czym tylko ostatni obszar jest zarazem celem strategii rozwoju) [Strategy 2014-2019, 2014: 5, 7].

Misją University of Rochester jest: ucz się, odkrywaj, uzdrawiaj, twórz i czyń świat coraz lepszym. W swojej wizji uczelnia podkreśla zaś, że zawsze będzie na każdym poziomie włączającą, sprawiedliwą, zrównoważoną i wrażliwą organizacją [Mission, Vision \& Values, 2019]. Także Copenhagen Business School nawiązuje w swojej misji do zrównoważonego rozwoju, stwierdzając, że obowiązkiem uczelni jest „,kształcenie (...) w celu tworzenia wartości i zrównoważonego rozwoju" [Strategy, 2019].

Zrównoważenie (ang. sustainability) jest jedną z kluczowych wartości w University of Leeds [Values and Responsibility, 2019]. Podobnie było do 2019 roku w University of Westminster (ale tutaj w ujęciu wąskim - ekorozwoju) [Vision, Mission and Values, 2018].

Metoda opracowania strategii SOU. Strategia SOU może zostać opracowana ekspercko (przez zespół powołany przez władze uczelni i/lub ekspertów zewnętrznych) i/lub partycypacyjnie, przy zaangażowaniu pracowników i innych interesariuszy, także zewnętrznych. Partycypacyjne opracowanie strategii SOU zwiększa z jednej strony stopień identyfikacji pracowników z tym dokumentem (przekładając się na ich zaangażowanie w jego realizację), a z drugiej gwarantuje, że podejmowane przez uczelnię działania odpowiadają na oczekiwania interesariuszy zewnętrznych, co zapewnia także legitymizację prowadzonej działalności.

Ponieważ w analizowanych strategiach SOU nie został omówiony sposób ich opracowania, to należy przypuszczać, że podobnie jak w przypadku strategii CSR przygotowywanych przez przedsiębiorstwa, większość strategii SOU została opracowana ekspercko. Tylko w nielicznych przypadkach uczelnie decydowały się na metodę ekspercko-partycypacyjną (jak na przykład Tilburg University). Niektóre, jak Universitat de Barcelona, w swoim ostatnim raporcie SOU, przygotowanym według wytycznych GRI, przyznają, że w najbliższej przyszłości z powodów proceduralnych interesariusze nie będą odgrywali bardziej znaczącej roli w określaniu treści raportów SOU przygotowywanych przez uczelnię (nie będą zatem brani pod uwagę przy określaniu istotności zagadnień SOU) [Report on Social Responsibility..., 2016: 17]. 


\section{Sposób zaangażowania interesariuszy w proces opracowania strategii} SOU. Według ISO26000 angażowanie interesariuszy to działanie podejmowane w celu stworzenia możliwości dialogu między organizacją i co najmniej jednym z interesariuszy, w celu zapewnienia odpowiednich informacji umożliwiających organizacji podejmowanie decyzji [PKN, 2012: 16]. Warto podkreślić, że ISO26000 uznaje identyfikowanie i angażowanie interesariuszy za jedną z dwóch fundamentalnych praktyk społecznej odpowiedzialności. Angażowanie interesariuszy w proces opracowania strategii SOU jest jednym z wymiarów angażowania interesariuszy w ogóle - pozwala z jednej strony poznać ich oczekiwania i uwzględnić je w zapisach strategii SOU, z drugiej - nawet włączyć w późniejszą realizację tego dokumentu.

Przy opracowaniu mapy interesariuszy Universitat de Barcelona brały udział jednostki administracyjne uczelni - nie tylko dokonywały identyfikacji grup interesariuszy, lecz także starały się określić rodzaj i częstotliwość kontaktów z nimi oraz pojawiąjące się przy tej okazji kwestie lub problemy [Report on Social Responsibility..., 2016: 13]. W Tilburg University przygotowana przez zarząd wstępna wizja strategicznego rozwoju została poddana szerokiej dyskusji ze wszystkimi interesariuszami uczelni (między innymi pracownikami, studentami, absolwentami, radą uczelni). Dyskusja toczona była zarówno w ramach spotkań Tilburg University Society (działającego od 2009 roku towarzystwa, w skład którego wchodzi około czterdziestu pięciu przedstawicieli administracji publicznej, biznesu i nauki), jak i mediów społecznościowych [Making the Difference..., 2014: 3].

W Polsce na przeprowadzenie badań ankietowych na potrzeby strategii SOU zdecydował się Uniwersytet Ekonomiczny we Wrocławiu (wśród studentów) oraz Szkoła Główna Handlowa w Warszawie (wśród pracowników i interesariuszy zewnętrznych).

Zakres strategii SOU (obszary, których dotyczy). Strategia SOU powinna odpowiadać na oczekiwania kluczowych interesariuszy uczelni i wypływać z rozpoznania przez uczelnię zakresu przedmiotowego i podmiotowego jej społecznej odpowiedzialności. Jak wskazują przytoczone wcześniej definicje USR/SOU, strategia SOU powinna obejmować podstawowe obszary działalności uczelni wynikające z jej misji, to jest edukację i badania oraz służbę społeczeństwu, a także zarządzanie uczelnią. Opracowanie funkcjonalnej strategii SOU (ograniczającej się do wybranego obszaru/obszarów) może rodzić ryzyko, że działania z zakresu społecznej odpowiedzialności będą realizowane wybiórczo, tylko w niektórych działach czy projektach.

Podstawowym wyrazem SOU powinno być kształcenie w zakresie społecznej odpowiedzialności i zrównoważonego rozwoju - w najnowszej edycji badań PRME i Macquarie Graduate School of Management (2016) 64,2\% badanych studentów uważa, że obowiązkowa dla wszystkich studentów szkół biznesowych powinna być tematyka etyki biznesu (74,2\% odpowiedzi ,zdecydowanie zgadzam się" i ,zgadzam się"), ekorozwoju (odpowiednio 71\%) i CSR $(63,1 \%)$. Co więcej, $65,1 \%$ studentów uznało, że ich uczelnia powinna postępować zgodnie z tym, czego uczy (ang. walk the talk) [Haski-Leventhal, Concato, 2016: 25].

University of the West of Scotland opracował zrównoważony plan (dotyczący przede wszystkim odpowiedzialności środowiskowej uczelni), w którym określa 
planowane działania uczelni w następujących obszarach: sukces studentów; badania, przedsiębiorczość i zaangażowanie; zasięg globalny; ludzie; finanse i infrastruktura [UWS Sustainability..., 2016]. Na opracowanie strategii SOU, choć ograniczającej się tylko do wymiaru środowiskowego, zdecydował się także Otago University z Nowej Zelandii (uznając ten obszar za wymagający szczególnej interwencji). Z kolei w południowoafrykańskim University of Pretoria SOU rozumiane jest jako szeroki program zaangażowania społecznego studentów na rzecz wsparcia społeczności lokalnych [About Us, 2019].

Jedyną strategią SOU w Polsce jest Strategia Społecznej Odpowiedzialności Wydziału Informatyki i Komunikacji z 2012 roku Uniwersytetu Ekonomicznego w Katowicach, która zawiera cztery cele, dotyczące: użyteczności badań, jakości kształcenia, wspierania pracowników, budowania marki [Raport społeczny 2012-2014: 16]. Prace nad opracowaniem strategii SOU prowadzi obecnie kilka innych polskich uczelni (na przykład Szkoła Główna Handlowa w Warszawie i Uniwersytet Ekonomiczny we Wrocławiu).

Podmiot odpowiedzialny za realizację strategii SOU. Punktem wyjścia procesu budowania strategii SOU jest powołanie osoby (zespołu) odpowiedzialnej za te kwestie. Formalizacja i usytuowanie osoby (zespołu) możliwie wysoko w hierarchii władzy w uczelni ma zagwarantować większe możliwości w realizowaniu strategii i koordynowaniu wynikających z niej działań.

Utworzony w 2012 roku w paryskiej ESSCA Ecole de Management Komitet Sterujący ESSCA do spraw zrównoważonego rozwoju i CSR, składający się z wykładowców, studentów, pracowników administracyjnych i kierownictwa, spotyka się trzy razy w roku. W 2014 roku uczelnia powołała dodatkowo menedżera do spraw zrównoważonego rozwoju. W Tilburg University zarząd powołał ośmioosobową grupę sterującą do spraw CSR (w której skład wchodzi między innymi dyrektorka HR i przedstawiciel studentów) [CSR program, 2019]. Komitet do spraw społecznej odpowiedzialności (osiemnaście osób) w Universitat de Barcelona został powołany przez rektora w 2011 roku [UB documents..., 2019].

W Polsce komisje rektorskie do spraw SOU (reprezentujące różne grupy interesariuszy wewnętrznych) zostały powołane: na Uniwersytecie Ekonomicznym w Poznaniu (jedenaście osób) w 2014 roku (wcześniej, w 2013 roku, powołany został pełnomocnik rektora do spraw społecznej odpowiedzialności uczelni) [Sprawozdania, 2019], w Szkole Głównej Handlowej w Warszawie w 2017 roku (czternaście osób) oraz na Uniwersytecie Ekonomicznym we Wrocławiu w 2017 roku (osiem osób, tylko przedstawiciele pracowników naukowych).

\section{Podsumowanie}

Polskie uczelnie są dopiero na początkowym etapie wdrażania SOU oraz budowania strategii społecznej odpowiedzialności. Interesujące jest, że w zasadzie prace nad wdrożeniem tej koncepcji są prowadzone na razie w uczelniach publicznych. Ze względu na brak jednoznacznych wzorców każda z uczelni może 
wybrać własną ścieżkę tworzenia, może również - w ramach benchmarku - skorzystać z wzorców zagranicznych, a także skonsultować podejście z uczelniami, które już podjęły takie działania w Polsce. Warto zwrócić uwagę na to, że strategia społecznej odpowiedzialności powinna być powiązana $\mathrm{z}$ ogólną strategią uczelni i odpowiadać także na wyzwania napływające z zewnątrz (zmiany społeczne, gospodarcze, środowiskowe) oraz budować kapitał społeczny u pracowników i studentów. Z kolei innowacyjność zapewnia się przez tworzenie zespołów składających się z osób reprezentujących różne obszary wiedzy, zróżnicowanych płciowo i wiekowo, a także narodowościowo. Do tego potrzebny jest kapitał społeczny i umiejętność prowadzenia dialogu w różnorodnym środowisku. Powyższe kompetencje, często określane jako miękkie, powinny być rozwijane już na wczesnym etapie edukacji.

Kolejnym obszarem istotnym z punktu widzenia budowania strategii społecznej odpowiedzialności jest transparentność prezentowanych informacji. Nie jest to zadanie łatwe przy niskim poziomie wskaźnika zaufania w Polsce, będącego podstawą kapitału społecznego. Dlatego tak ważne jest podjęcie takich działań przez władze uczelni w stosunku do pracowników i studentów, które mają na celu budowanie świadomości społecznej odpowiedzialności, a także wspierają budowę kapitału społecznego. Wszelkie intencje, które za nimi stoją, powinny być przejrzyste i zrozumiałe dla wszystkich wewnętrznych interesariuszy i razem z nimi ustalane. Istotnym zagrożeniem z punktu widzenia wdrażania SOU jest wpisanie tej koncepcji w strategię (ogólną bądź strategię SOU) bez zapewnienia jej operacyjnego wdrażania i stosowania w ramach wszelkich procedur uczelni (SOU jawi się wówczas jedynie jako deklaracja strategiczna).

\section{Bibliografia}

About Us (2019), The University of Pretoria (UP), www.up.ac.za/usr/article/2650972/ preview? module $=$ cms\&slug=content-item\&id=2650972 [dostęp: 18.03.2019].

Białoń L., Werner E. (2012), Społeczna odpowiedzialność szkoły wyższej w kontekście jej wizerunku, „Nauka i szkolnictwo wyższe”, 1, 39.

Boyer E.L. (1996), From Scholarship Reconsidered to Scholarship Assessed, „Quest”, 48(2).

Chandler A.D. (1962), Strategy and Structure. Chapters in History of Industrial Enterprise, MIT Press, Cambridge (Mass.).

Chmielecka E. (2008), Kilka uwag o etosie i kodeksach akademickich oraz o odpowiedzialności uczelni [w:] K. Leja (red.), Spoleczna odpowiedzialność uczelni, Wydawnictwo Politechniki Gdańskiej, Gdańsk.

CSR program (2019), www.tilburguniversity.edu/about/tilburg-university/csr/sustainability/ program/ [dostęp: 18.03.2019].

Cybal-Michalska A. (2015), Społeczna odpowiedzialność uczelni wyższych, „Rocznik Lubuski", 41, cz. 2.

Deklaracja Społecznej Odpowiedzialności Uczelni (2017), https://uni.wroc.pl/wp-content/uploads/2017/11/Deklaracja-Spolecznej_Odpowiedzialnosci_Uczelni.pdf [dostęp: 18.03.2019]. 
Esfijani A., Hussain F.K., Chang E. (2013), University Social Responsibility Ontology, „Engineering Intelligent Systems", 21, 4.

Esfijani A. (2014), Methodology Development for Measuring Virtual University Social Responsibility, doctoral thesis, Curtin University, https:/espace.curtin.edu.au/bitstream/ handle/20.500.11937/488/199910_Esfijani\%202014.pdf?sequence=2\&isAllowed=y [dostęp: 18.03.2019].

Gałat W. (2018), Deklaracja społecznej odpowiedzialności uczelni jako wzmocnienie etosu akademickiego, „Zeszyty Naukowe Uniwersytetu Ekonomicznego w Krakowie”, 6, 978.

Geryk M. (2010), Społeczna odpowiedzialność uczelni, Oficyna Wydawnicza SGH, Warszawa.

Geryk M. (2012), Społeczna odpowiedzialność uczelni w percepcji jej interesariuszy. Raport z badań, Oficyna Wydawnicza SGH, Warszawa.

Guidelines for Universities Engaging in Social Responsibility (2017), Erasmus+ Unibility, http://www.iau-hesd.net/sites/default/files/documents/io8_guidelines_final_version_ 2017-09-12_print.pdf [dostęp: 18.03.2019].

Haski-Leventhal D., Concato J. (2016), The State of CSR and RME in Business Schools and the Attitudes of Their Students. Third Bi-annual Study, MGSM, PRME, http://www.unprme.org/resource-docs/MGSMPRMEReport2016.pdf [dostęp: 18.03.2019].

Iwankiewicz-Rak B., Shulgina L. (2013), Misja-marka - wizerunek uczelni-relacje z otoczeniem [w:] G. Nowaczyk, D. Sobolewski (red.), Marketing w szkole wyższej. Istota i znaczenie marki, Wydawnictwo Wyższej Szkoły Bankowej, Poznań.

Koj A. (2013), Ewolucja idei uniwersytetu i jego misji [w:] J. Woźnicki (red.), Misja i stużebność uniwersytetu $w$ XXI wieku, Instytut Społeczeństwa Wiedzy, Fundacja Rektorów Polskich, Warszawa.

Leja K. (2008), Uniwersytet organizacja stużąca otoczeniu [w:] K. Leja (red.), Spoteczna odpowiedzialność uczelni, Wydawnictwo Politechniki Gdańskiej, Gdańsk.

Leja K. (2009), Uniwersytet społecznie odpowiedzialny - przykład AGH, „E-mentor”, 4, 31.

Lloyd B. (1992), Mintzberg on The Rise and Fall of Strategic Planning, „Long Range Planning", 25, 4.

Making the Difference. Strategy 2014-2017 (2014), www.tilburguniversity.edu/upload/8f3fe2da-16ae-4c0b-b81e-2e70bda633be_STRATEGISCH_PLAN_UK.pdf [dostęp: 18.03.2019].

Manchester 2020. The University of Manchester's Strategic Plan (2015), http://documents. manchester.ac.uk/display.aspx?DocID=25548 [dostęp: 18.03.2019].

Markides C. (2004), What Is Strategy and How do You Know if You Have One?, „Business Strategy Review", 15, 2.

Mintzberg H., Ahlstrand B., Lampel J. (1998), Strategy Safari. A Guided Tour through the Wilds of Strategic Management, Free Press, New York.

Mission, Vision \& Values (2019), www.rochester.edu/aboutus/mission.html [dostęp: 18.03.2019].

Navarrete E.E. i in. (2012), Preliminary Analysis of Social Responsibility inside Chilean Universities, „African Journal of Business Management”, 6, 42.

Nejati M., Shafaei A., Salamzadeh Y., Daraei M. (2011), Corporate Social Responsibility and Universities: A Study of Top 10 World Universities' Websites, „African Journal of Business Management", Vol. 5, No. 2.

Obłój K. (2007), Strategia organizacji. W poszukiwaniu trwałej przewagi konkurencyjnej, Polskie Wydawnictwo Ekonomiczne, Warszawa. 
PKN (2012), Norma PN-ISO26000. Wytyczne dotyczace spolecznej odpowiedzialności, Warszawa.

PRME - The Principles for Responsible Management Education (2019), http://ue.poznan. $\mathrm{pl} / \mathrm{pl} /$ uniwersytet,c13/certyfikaty-i-akredytacje,c83/prme-the-principles-for-responsible-management-education,a73914.html [dostęp: 18.03.2019].

Raport spoleczny 2012-2014, Wydział Informatyki i Komunikacji Uniwersytet Ekonomiczny w Katowicach, www.ue.katowice.pl/fileadmin/_migrated/content_uploads/raport_spoleczny_WIiK_lipiec2014.pdf [dostęp: 18.03.2019].

Reiser J. (2007), Managing University Social Responsibility (USR) [w:] International Sustainable Campus Network: Best Practices-Future Challenges, www.international-sustainable-campus-network.org/downloads/conference-and-symposia/iscn-conference-2007/108-panel-bl-juan-reiser-pontificia-universidad-catolica-del-peru/file [dostęp: 18.03.2019].

Report on Social Responsibility University of Barcelona 2015-2016 (2016), www.ub.edu/responsabilitatsocial/docs/en/memoria2015-16_ang.pdf [dostęp: 18.03.2019].

Search Participants, www.unprme.org/participation/search-participants.php [dostęp: 18.03.2019]. Six Principles (2019), www.unprme.org/about-prme/the-six-principles.php [dostęp: 18.03.2019]. Sprawozdania (2019), http:/ue.poznan.pl/pl/uniwersytet,c13/wladze,c12/komisja-rektorska-ds-spolecznej-odpowiedzialnosci-uczelni,c3628/sprawozdania,a27201.html [dostęp: 18.03.2019].

Strategy 2014-2019 (2014), University of London, https://london.ac.uk/sites/default/files/2017-10/University_of_London_Strategy_2014-19.pdf [dostęp: 18.03.2019].

Strategy (2019), www.cbs.dk/en/about-cbs/strategy [dostęp: 18.03.2019].

Szewior K. (2018), Uwarunkowania i doświadczenia społecznej odpowiedzialności uczelni w środowisku lokalnym Polski, „Myśl Ekonomiczna i Polityczna”, 1, 60.

Talloires Declaration (2019), http://ulsf.org/talloires-declaration/ [dostęp: 18.03.2019].

The Talloires Declaration. 10 Point Action Plan (1990), http://ulsf.org/wp-content/uploads/2015/06/TD.pdf [dostęp: 18.03.2019].

UB documents on the integration of social responsibility policies into institutional management (2019), www.ub.edu/responsabilitatsocial/en/documents.html [dostęp: 18.03.2019].

University of London (2017), Corporate Social Responsibility Statement, https://london. ac.uk/sites/default/files/2017-10/Corporate_Social_Responsibility_Statement_external. pdf [dostęp: 18.03.2019].

University Social Responsibility: A Common European Reference Framework (2015), Final Public Report of the EU-USR Project, www.eu-usr.eu/wp-content/uploads/2015/04/D1.4-Final-Report-Public-Part-EN.pdf [dostęp: 18.03.2019].

UWS Commitments (2019), www.uws.ac.uk/about-uws/uws-commitments/ [dostęp: 18.03.2019].

UWS Sustainability Plan 2016 to 2020 (2016), University of the West of Scotland, www.uws. ac.uk/media/4080/uws_sus_plan_2016-2020.pdf [dostęp: 18.03.2019].

Values and Responsibility (2019), www.leeds.ac.uk/info/5000/about/136/values_and_responsibility [dostęp: 18.03.2019].

Vasilescu R., Barna C., Epure M., Baicu C. (2010), Developing University Social Responsibility: A Model for the Challenges of the New Civil Society, „Procedia Social and Behavioral Sciences", 2, 2.

Vision, Mission and Values (2018), www.westminster.ac.uk/about-us/our-university/vision-mission-and-values [dostęp: 18.03.2019]. 